Svitlana Andros,

D.Sc., Associate Professor, National Science Center «Institute of Agrarian Economics», Ukraine

Ludmila Melnyk,

D.Sc., Associate Professor, Uman National University of Horticulture, Ukraine

Nataliia Butenko,

D.Sc., Professor, National Taras Shevchenko University of Kyiv, Ukraine

Hanna Zaikina,

Ph.D., Ukrainian State Universiti of Railway Transport, Ukraine

Volodymyr Tykhenko,

Ph.D., Sumy State University, Ukraine

\title{
EFFICIENCY OF MANAGEMENT OF LOAN FUNDS IN THE BANKING INDUSTRY OF UKRAINE: DATA OF THE FACTOR ANALYSIS OF CREDIT TURNOVER
}

Abstract. The article analyzes the rates of credit turnover by branches of the economy and by types of loans using indicators of the dynamic range, indices of average values and aggregate indicators. The purpose of the article is to provide a business case for efficiently managing credit resources in commercial banks based on a factor analysis of credit turnover by sector of the economy as a condition for optimizing a bank's activities. The analysis of the literature shows that the management of credit resources in commercial banks is limited to the use of Western methods that are not adapted to the Ukrainian reality. The relevance of the article is the need to use the methods of economic and mathematical modeling to optimize the process of managing borrowed funds in the banking industry of Ukraine. Calculated average balances of credit investments. The article analyzes the hourly repayment of interest on loans by enterprises. Calculations of the volume of credit turnover are based on real indicators of the financial statements of Credit Agricole Bank. The study period was elected 2016-2017. Calculated the share of loans by industry in the portfolio of the bank. Defined one-day turnover on the repayment of bank loans by business entities. Calculated the duration of use of bank loans by business entities. The factors affecting the change in the rate of turnover of credit operations using the index method are analyzed. The index of the average duration of use of the loan of a constant composition is calculated. The average duration of use of bank loans by business entities has been determined. The structural change index, variable composition index, constant composition index, structure influence index are calculated. The article used the methods of factor analysis, probability theory, methods of economic and mathematical statistics. The effectiveness of borrowed funds management in the banking industry of Ukraine (on the example of Credit Agricole Bank) was confirmed by the data of a factor analysis of the loan turnover. The system of tasks solved by the proposed models includes the calculation of reasonable limits for attracting each type of resources and the effective interest rate to ensure increasing returns from the production of bank credit products and an increase in the share of the banking sector in creating the gross domestic product of the country.

Keywords: bank, effective, index, credit turnover, position, interest rate, sum, term, manager.

Introduction. The turnover of credit investments of the bank is an indicator of the activity of the bank in the credit market. Acceleration or deceleration of loan turnover does not affect the level of income of a bank, but it is a qualitative characteristic of the credit process (Athanasoglou et al., 2008). A slowdown in loan turnover, ceteris paribus, means an increase in investments with longer repayment periods, the issuance of loans for longer repayment periods, and often deterioration in the quality of the loan portfolio indicates an increase in deferred and overdue debts. At the same time, a slowdown in loan turnover worsens the liquidity of the bank's assets. In addition, it is possible to judge the credibility of the bank's reports through the loan turnover indicator.

When analysing the lending activities of banks, financial analysts do not pay enough attention to the study of the timing and rate of credit turnover (Golin, 2001). As you know, loan portfolio analysis can be carried out in different directions: type of counterparties, types and terms of loans, nature of debt,

Cite as: Andros, S., Melnyk, L., Butenko, N., Zaikina, H. \& Tykhenko, V. (2019). Efficiency of Management of Loan Funds in the Banking Industry of Ukraine: Data of the Factor Analysis of Credit Turnover. Marketing and Management of Innovations, 4, 129-139. http://doi.org/10.21272/mmi.2019.4-11 

Industry of Ukraine: Data of the Factor Analysis of Credit Turnover

industry sector (Dietsch and Petey, 2002). Analysis of the portfolio by industry sector implies consideration of the level of diversification and credit turnover. The quality of the loan portfolio essentially depends on the sectors in which the bank invests financial resources. When lending to industries in financial difficulty, the bank may incur losses (Behr and Guettler, 2007). In order to reduce credit losses, we consider it expedient to periodically classify industries by level of credit risk (Berger and Udell, 1998).

Literature Review. Problems associated with the influence of bank assets on its liquidity, financial stability and reliability are considered in a large number of works (Athanasoglou, Brissimis and Delis, 2008; Tan and Anchor, 2016). Mathematic methods of banking modelling were proposed by Sufian and Habibullah, 2009, the most significant contribution to the construction of models of functioning and management in the bank was made by Brignall, 2007; Lebas, 1995. A significant contribution to the development of methods for optimizing and managing credit resources belongs to Kotane, KuzminaMerlino, 2012. Methods of modelling asset quality for the purpose of rating the bank developed by Brcak, 2010; optimal control models - Neely, 2004. The justification of the methodological approach to the management of banking resources in the conditions of the market model of the economy remains beyond the scope of many domestic studies, as often the management of credit resources in banks is limited to the use of Western methods that are not adapted to Ukrainian realities. Therefore, in the models of many authors on the effective management of credit resources in commercial banks (Conti, Fruhwirth-Schnatter, Heckmanc, Piateke, 2014) there are many restrictions on their use. In addition, the system of tasks solved by these models does not include the calculation of reasonable limits for attracting each type of resources and the effective interest rate to ensure increasing returns from the production of banking products; increasing the share of the banking sector in creating the country's gross domestic product.

The high-tech industries feel the greatest risk of financial losses and bankruptcy due to the possible obsolescence of products and high costs of scientific research, as well as due to the economic crisis: heavy industry, instrument-making, automotive (Jac et al., 2013). Enterprises of the agro-industrial complex and the food industry and the trade sector are primarily oriented towards the mass consumer; operate in labour-intensive industries (Civelek and Kljucnikov, 2018). In contrast to capital-intensive businesses, enterprises of the agro-industrial complex have a more stable financial condition, because they have higher profit margins and a turnover rate of funds, including loans (Hornungova and Milichovsky, 2016). The Bank ranks the level of credit risk when considering a loan application. It is advisable to diversify the loan portfolio among a larger number of industries and by type of loan (Dohcheva, 2009). We consider it expedient to analyse the loan portfolio from the composition and structure, and interest rates, as well as in terms of the turnover rate and timing of credit use.

Results. Indicators Credit turnover rate indicators by sectors of the real sector of the economy and by types of loans can be calculated using dynamic range indicators (growth rates and growth and absolute growth) (Kotane, Kuzmina-Merlino, 2012), as well as using average value indices and aggregate indices (Heffernan and $\mathrm{Fu}, 2010$ ). The information base for the analysis is the data of the annual financial statements of Credit Agricole Bank (Annual Financial Ctatements of «Credit Agricole Bank», 2017). The analysis should begin with a study of the average loan balance (Table 1).

Credit Agricole Bank focuses on cooperation with the agricultural sector, offering customers a combination of agricultural and financial expertise, as well as innovative solutions for the Ukrainian market. Credits granted to legal entities include all loans from the business segment «Small and Medium-Sized Businesses and Corporations», regardless of the purpose of the loan. Mortgage loans to individuals include loans provided for the purchase of real estate. Consumer loans to individuals include car loans and cash unsecured loans. We calculate the average balances of credit investments according to the average chronological formula for the moment series of dynamics. In doing so, we use the data of the financial statements «Credit Agricole Bank». In 2017 compared to 2016, the average loan balances 
S. Andros, L. Melnyk, N. Butenko, H. Zaikina \& V. Tykhenko. Efficiency of Management of Loan Funds in the Banking Industry of Ukraine: Data of the Factor Analysis of Credit Turnover

decreased by UAH 1,489.3 million. The growth rate of the indicator together for the loan portfolio amounted to $57.9 \%$ (Table 1).

Table 1. The balance of loans and customer debts of Credit Agricole Bank, 2016-2017, thousand UAH

\begin{tabular}{|c|c|c|c|c|c|c|}
\hline \multirow[t]{2}{*}{ Type of loan } & \multicolumn{2}{|c|}{$\begin{array}{l}\text { The balance of the loan at the } \\
\text { end of the year, thousand UAH }\end{array}$} & \multicolumn{2}{|c|}{$\begin{array}{c}\text { Impaired loans, thousand } \\
\text { UAH }\end{array}$} & \multirow{2}{*}{$\begin{array}{c}\text { Absolute } \\
\text { deviation, } \\
\text { thousand UAH }\end{array}$} & \multirow{2}{*}{$\begin{array}{c}\text { Rates of } \\
\text { growth, } \\
\%\end{array}$} \\
\hline & 2016 & 2017 & 2016 & 2017 & & \\
\hline Loans to legal entities & (3 290 273) & $(1970374)$ & 3818558 & 1899742 & -1319899 & 59,9 \\
\hline $\begin{array}{l}\text { Mortgage loans to } \\
\text { individuals }\end{array}$ & (151 876) & (27 281) & 154816 & 25734 & -124 595 & 17,96 \\
\hline $\begin{array}{c}\text { Consumer loans } \\
\text { granted to individuals }\end{array}$ & (93 529) & (48 693) & 91876 & 43935 & -44836 & 52,06 \\
\hline Total loan portfolio & (3535 678) & (2 046348$)$ & 4065250 & 1969411 & -1489330 & 57,9 \\
\hline
\end{tabular}

Source: developed by authors.

The favourable economic situation created a reliable financial basis for the activities of small and medium-sized businesses and corporations and led to a reduction in debt in 2017 by UAH 1319.9 million. The balances on mortgage and consumer loans granted to individuals in 2017 decreased by UAH 124.6 million and UAH 44.8 million, respectively. The decrease in loan debt balances and overdue loans in the portfolio as a whole by UAH 2,095.8 million in 2017 led to an improvement in the quality of the loan portfolio of Credit Agricole Bank. Table 2 shows the structure of loans by industry.

Table. 2. Structure of loans by industry credit of Credit Agricole Bank, 2016-2017, thousand UAH

\begin{tabular}{|c|c|c|c|c|}
\hline \multirow{2}{*}{ Type of economic activity } & \multicolumn{2}{|c|}{$\begin{array}{c}\text { Loan amount, } \\
\text { thousand UAH }\end{array}$} & $\begin{array}{c}\text { Absolute } \\
\text { deviation, } \\
\text { thousand UAH }\end{array}$ & $\begin{array}{c}\text { Rates of } \\
\text { growth, } \\
\%\end{array}$ \\
\cline { 2 - 5 } & 2016 & 2017 & -1048341 & 86,7 \\
\hline Wholesale and retail trade & 7867604 & 6819263 & +1900377 & 141,6 \\
\hline Processing industry & 4565087 & 6465464 & +1977 \\
\hline Agriculture, hunting and forestry & 3874735 & 4178850 & +304115 & 107,8 \\
\hline Individuals & 2187361 & 3162061 & $+974,700$ & 144,6 \\
\hline Transport, warehousing, postal and courier activities & 314611 & 574275 & +259664 & 182,5 \\
\hline Other & 123192 & 239596 & +116404 & 194,5 \\
\hline Real Estate Operations & 102547 & - & +102547 & - \\
\hline Administrative and support services & 5878 & - & - & - \\
\hline Total loans and customer debts before reserves & $\mathbf{1 9 0 4 1 0 1 5}$ & $\mathbf{2 1 4 3 9 5 0 9}$ & $\mathbf{+ 2 ~ 3 9 8 4 9 4}$ & $\mathbf{1 1 2 , 6}$ \\
\hline
\end{tabular}

Source: developed by authors.

Analyse the amount of loans by industry sector and customer debt. In 2017, compared to 2016, credit resources increased by UAH 2,398.5 million, and the rate of growth of the indicator was $112.6 \%$ (Table 2). Slow growth in the economy created a more or less favourable financial basis for agriculture, which led to an increase in lending to this industry in 2017 by UAH 304.1 million compared with a significant decrease in loans to wholesale and retail enterprises by UAH 1048.3 million, respectively. The loan portfolio, formed from customers of wholesale and retail trade, experienced the influence of unfavourable factors of competition, falling demand types of goods. This industry was particularly susceptible to the influence of macroeconomic factors: the loss of part of the sales markets, the 
S. Andros, L. Melnyk, N. Butenko, H. Zaikina \& V. Tykhenko. Efficiency of Management of Loan Funds in the Banking Industry of Ukraine: Data of the Factor Analysis of Credit Turnover

deterioration of the terms of trade. Table 3 provides an analysis of the quality of loans provided by Credit Agricole Bank.

As can be seen in table 3, in 2017 the number of large borrowers with a credit history of more than 2 years (in 2016.1 million UAH) compared with 2016 significantly increased in the loan portfolio of the bank.

Table. 3. Analysis of credit quality of Credit Agricole Bank, 2016-2017, thousand UAH

\begin{tabular}{|c|c|c|c|c|}
\hline \multirow{2}{*}{ Article title } & \multicolumn{2}{|c|}{$\begin{array}{c}\text { Not overdue and not depreciated } \\
\text { loans at the end of the year, th. } \\
\text { UAH }\end{array}$} & $\begin{array}{c}\text { Absolute deviation, } \\
\text { th. UAH }\end{array}$ & $\begin{array}{c}\text { Rates of } \\
\text { growth, } \\
\%\end{array}$ \\
\cline { 2 - 3 } & 2016 & 2017 & & 117,9 \\
\hline $\begin{array}{c}\text { Large borrowers with a credit history of more } \\
\text { than 2 years }\end{array}$ & 11255396 & 13271487 & +2016091 & +797666 \\
\hline New large borrowers & 401059 & 1198725 & 298,9 \\
\hline Loans to medium-sized companies & 621136 & 966072 & +344936 & 155,5 \\
\hline Loans to small companies & 419527 & 880490 & +460963 & 209,9 \\
\hline Loans to individuals:: & 1902716 & 3002953 & +1100237 & 157,8 \\
\hline - class A & 891787 & 2768010 & +1876223 & 310,4 \\
\hline - class D & 1010403 & 218051 & -792352 & 21,6 \\
\hline - class B & 526 & 6136 & +5610 & 1166,5 \\
\hline - class 「 & - & 10756 & - & - \\
\hline
\end{tabular}

Note: Class A - the financial condition of the borrower is good, the level of solvency is high. Class B - the financial condition of the borrower is satisfactory, the increased probability of late payment of the debt. Class $B$ - the financial condition of the borrower is unsatisfactory, the likelihood of late repayment is high. Class $\mathrm{G}$ - the financial condition of the borrower is critical, the probability of default on debt is high.

Source: developed by authors.

During this period, there is a tendency to increase the number of new large borrowers by UAH 797.7 million and loans to small companies by UAH 460.9 million, respectively. In 2017, there is a high probability of non-repayment of debt by individuals-borrowers, caused by their critical financial situation: the level of overdue loans increased by 5.6 thousand UAH compared to 2016 ( 0.53 thousand UAH). The decline in real incomes of the population, decline in production and consolidation of the loss-making tendencies of retail enterprises, high inflation, devaluation of the $\mathrm{UAH}$, the social situation in Ukraine, as well as military actions in the East have made it impossible for borrowers to fulfil their obligations in a timely manner. The growth of loan debt, overdue and bad loans of individuals in class $\mathrm{G}$ amounted to UAH 10.756 million in 2017, which led to deterioration in the quality of the loan portfolio for Credit Agricole Bank as a whole. Table 4 shows the repayment of loans by business entities in 2016-2017.

Table. 4. Repayment of loans by business entities of Credit Agricole Bank, 2016-2017, thousand UAH

\begin{tabular}{|l|c|c|c|c|c|c|}
\hline \multicolumn{1}{|c|}{ Type of loan } & \multicolumn{2}{|c|}{$\begin{array}{c}\text { Structure of average loan } \\
\text { balances in relation to the } \\
\text { portfolio as a whole, \% }\end{array}$} & $\begin{array}{c}\text { Not overdue and not } \\
\text { depreciated loans at the end } \\
\text { of the year, } \\
\text { th. UAH }\end{array}$ & $\begin{array}{c}\text { The number of } \\
\text { turns of the loan }\end{array}$ \\
\cline { 2 - 7 } & 2016 & 2017 & 2016 & 2017 & 2016 & 2017 \\
\hline Loans to legal entities & 93,059 & 96,287 & 12697118 & 16316774 & 3,86 & 8,28 \\
\hline Mortgage loans to individuals & 4,295 & 1,333 & 75079 & 63117 & 0,49 & 2,31 \\
\hline Consumer loans to individuals & 2,645 & 2,379 & 1827637 & 2939836 & 19,54 & 60,37 \\
\hline Total loan portfolio & $\mathbf{1 0 0}$ & $\mathbf{1 0 0}$ & $\mathbf{1 4 5 9 9 8 3 4}$ & $\mathbf{1 9 3 1 9 7 2 7}$ & $\mathbf{4 , 1 2}$ & $\mathbf{9 , 4 4}$ \\
\hline
\end{tabular}

Source: developed by authors. 
S. Andros, L. Melnyk, N. Butenko, H. Zaikina \& V. Tykhenko. Efficiency of Management of Loan Funds in the Banking Industry of Ukraine: Data of the Factor Analysis of Credit Turnover

As can be seen in table 4, in 2017 the level of repayment of loans extended to legal entities and consumer loans extended to individuals increased by $28.5 \%$ (16316 $774 / 12697118=1.285)$ and $60.9 \%$ (2939836/1827637=1.608) accordingly, mortgage loans granted to individuals decreased by $16.0 \%$ (84$100) ;(63117 / 75079=0.84)$. The level of repayment of loans provided to legal entities and consumer loans granted to individuals increased in 2017. This is a positive trend (Brcak, 2010; Shih et al., 2007). Factor analysis is supported by conducting credit monitoring and continuous assessment of the quality of the loan portfolio (Tan and Anchor, 2016), (Table 3). Credit monitoring consists of a procedure for monitoring the repayment of loans and activities that accomplish this task (Khalid and Kalsom, 2014). Credit checks help the bank's management, on the one hand, to identify problem loans, as well as assess the aggregate credit risk, and, on the other hand, to carry out the necessary preventive measures towards strengthening the financial sustainability of Credit Agricole Bank. Credit monitoring includes: periodic checking of all types of loans, including checking every 30,60 or 90 days of all large loans and selectively checking small loans; credit control, which includes the analysis of timeliness and completeness of payments, the provision of credit, reliability of information, assessment of changes in the financial situation (Conti et al., 2014). Financiers need to know the amount of credit turnover by industry sector and by type of loan for the reporting and base period, including the structure of average credit balances (Roodman, 2009). Calculate the amount of credit turnover, using the data in Table 4.

$12,697,118 / 3,290,273=3.86(2016) ; 16,316,774 / 1970,374=8.28$ (2017), etc. We define the structure of average loan balances. In 2016, the share of loans granted to legal entities was $93.06 \%$ $(3,290,273 / 3,535,678)$, mortgage loans to individuals amounted to $4.295 \%(151,876 / 3,535,678)$ and, finally, consumer loans provided to individuals 2.65\% (93 529/3535 678). In 2017, the share of average loan balances was $96.29 \%$ (1,970,374/2,046,348); 1.33\% (27281/2046348); 2.38\% (48 693/2 046 348), respectively. Table 4 shows the results of calculations.

Problem solving. We calculate the share of loans by economic activity in the Credit Agricole Bank portfolio (Table 5), using the data in table 2.

In 2016, the largest share of loans by industry in the loan portfolio of the bank accounted for wholesale and retail trade $-41.3 \%(7867604 / 19041015=0.413)$. In second place is the processing industry and agriculture, hunting and forestry $-23.98 \%$ and $20.35 \%$, respectively. In 2017 , the bank changed its priorities in lending to the processing industry: the share of loans in the bank's portfolio was already $30.2 \%$. The share of loans in agriculture and substantially in wholesale and retail trade decreased slightly $-19.49 \%$ and $31.8 \%$, respectively (although the share of loans remains large). In 2017 , the bank absolutely refused to credit real estate transactions.

Table. 5. Share of loans by sectors of the real sector of the economy in the Credit Agricole Bank portfolio, 2016-2017, \%

\begin{tabular}{|c|c|c|c|}
\hline \multirow{2}{*}{ Type of economic activity } & \multicolumn{2}{|c|}{$\begin{array}{c}\text { Loan share in the bank's } \\
\text { portfolio, } \%\end{array}$} & $\begin{array}{c}\text { Rates of } \\
\text { growth, } \\
\%\end{array}$ \\
\cline { 2 - 3 } & 2016 & 2017 & 717 \\
\hline Wholesale and retail trade & 41,3 & 31,8 & 76,9 \\
\hline Processing industry & 23,98 & 30,2 & 125,8 \\
\hline Agriculture, hunting and forestry & 20,35 & 19,49 & 95,8 \\
\hline Individuals & 11,487 & 14,75 & 128,4 \\
\hline Other & 1,65 & 2,68 & 162,3 \\
\hline Transport, warehousing, postal and courier activities & 0,64 & 1,12 & 174,5 \\
\hline Real Estate Operations & 0,538 & 0 & - \\
\hline Administrative and support services & 0,03 & 0 & - \\
\hline Total loans and customer debts before reserves are deducted & 100 & 100 & - \\
\hline
\end{tabular}

Source: developed by authors. 
S. Andros, L. Melnyk, N. Butenko, H. Zaikina \& V. Tykhenko. Efficiency of Management of Loan Funds in the Banking Industry of Ukraine: Data of the Factor Analysis of Credit Turnover

The data in table 5 allow us to draw conclusions about the excessive orientation of the bank towards lending to the wholesale and retail trade and the processing industry in 2017 . We believe that it is advisable for the bank to change the structure of credit investments, since; on the one hand, enterprises in this area are in the group with increased credit risk, and on the other, as a preliminary analysis showed, and the loan portfolio formed by the wholesale and retail trade is of poor quality. Table 6 shows the calculation of one-day turnover on the repayment of bank loans by business entities.

Table. 6. One-day turnover on repayment of loans to Credit Agricole Bank, business entities, 2016-2017

\begin{tabular}{|c|c|c|c|c|}
\hline \multirow{2}{*}{ Type of loan } & \multicolumn{2}{|c|}{$\begin{array}{c}\text { One-day turnover on loan repayment, } \\
\text { million UAH }\end{array}$} & $\begin{array}{c}\text { Absolute } \\
\text { deviation, million } \\
\text { UAH }\end{array}$ & $\begin{array}{c}\text { Rates of } \\
\text { growth, } \\
\%\end{array}$ \\
\cline { 2 - 3 } & 2016 & 2017 & $+10054,6$ & 128,5 \\
\hline Loans to legal entities & 35269,77 & 45324,4 & $-33,2$ & 84,07 \\
\hline Mortgage loans to individuals & 208,55 & 175,33 & $+3089,4$ & 160,85 \\
\hline Consumer loans to individuals & 5076,769 & 8166,2 & $+13110,8$ & 132,3 \\
\hline Total loan portfolio & 40555,09 & $\mathbf{5 3 6 6 5 , 9}$ & $\mathbf{2 0}$ \\
\hline
\end{tabular}

Source: developed by authors.

We calculate the one-day repayment turnover as the ratio of the amount of non-overdue and nondepreciated loans to the duration of the fiscal year using the data in Table 4: $12697118 / 360=35,269.77$; $75079 / 360=208.55 ; 1827637 / 360=5,076.769$. In general, in 2016 , the one-day redemption turnover in the loan portfolio amounted to UAH 40555090000 while in 2017, the loan portfolio amounted to UAH $19319727 / 360=53665908$ (Table 6). Table 7 presents the duration of the use of loans by subjects credited by the bank.

Using the data in Tables 1 and 6, we calculate the average terms for using loans: legal entities $3,290,273 / 35,269.77=93.3$ days; mortgage loans to individuals $-151,876 / 208.55=728.2$ days; consumer loans to individuals $-93529 / 5076,769=18.4$ days. In general, in the loan portfolio in 2016 , the duration of use of loans by subjects amounted to $3,535,678 / 40,555.09=87.2$ days and for the loan portfolio in 2017: $2,046,348 / 53,665.9=38.1$ days. The average loan life characterizes the average value of the gap (in days) between the issuance and repayment of individual loans. The results of the study show that there is a tendency to a significant slowdown in the turnover of mortgage loans to individuals (572.6), loans granted to legal entities (49.8), consumer loans granted to individuals: (12.5) under the influence of changes in the structure of loan debt (Table 7).

Table. 7. Duration of use of loans by entities credited to Credit Agricole Bank, 2016-2017

\begin{tabular}{|c|c|c|c|c|}
\hline \multirow{2}{*}{ Type of loan } & \multicolumn{2}{|c|}{ Duration of use of credits in days } & $\begin{array}{c}\text { Absolute deviation in } \\
\text { days }\end{array}$ & $\begin{array}{c}\text { Rates of growth, } \\
\%\end{array}$ \\
\cline { 2 - 5 } & 2016 & 2017 & $-49,8$ & 46,6 \\
\hline Loans to legal entities & 93,3 & 43,5 & $-572,6$ & 21,4 \\
\hline Mortgage loans to individuals & 728,2 & 155,6 & $-12,5$ & 32,1 \\
\hline Consumer loans to individuals & 18,4 & 5,9 & $-49,1$ & 43,7 \\
\hline Total loan portfolio & $\mathbf{8 7 , 2}$ & $\mathbf{3 8 , 1}$ & \multicolumn{2}{c}{} \\
\hline
\end{tabular}

Source: developed by authors.

The data in tables 6 and 7 show that the rate of credit turnover and the terms for using a loan vary considerably by type of loan and by subjects credited by Credit Agricole Bank. We are talking about mortgage loans provided to individuals for the purchase of real estate, which accompany quite large risks (O'sullivan et al., 2009). Risks are more related to lower real estate prices, changes in the exchange rate and interest rate, loss or decrease in borrower's income, possible loss of housing, 
S. Andros, L. Melnyk, N. Butenko, H. Zaikina \& V. Tykhenko. Efficiency of Management of Loan Funds in the Banking Industry of Ukraine: Data of the Factor Analysis of Credit Turnover

damage to property, and loss of customer health (Neely, 2004). Thus, the bank should take into account industry specifics when determining the optimal loan terms (Zhang, et al., 2015). The duration of immobilization of loans as a whole in all subjects decreased by 49.1 days (38.1-87.2).

To analyze the loan turnover, we will use the index method (Golin, 2001). The index method allows analyzing the factors of change in the rate of turnover of credit operations (Sufian and Habibullah, 2009). In this case, indices of average and aggregate values are used (Cernohorska and Kula, 2017). The system of indices of average values includes indices of variable and constant composition and the index of the influence of structural changes. The index of variable composition is the ratio of the average level of the phenomenon in the reporting period and the average value in the base period (Athanasoglou et al., 2008). The index of the average duration of use of a loan of variable composition is equal to:

$$
I_{t}=\bar{t}_{1} \div \bar{t}_{0}
$$

where $\mathrm{t}$ - is the one-day loan repayment turnover.

The value of the index of variable composition is influenced by two factors: the change in the duration of the use of short-term credit of individual units of the population; change in the share of oneday turnover on the redemption of individual parts of the aggregate in its total value over the entire set (Heffernan and $\mathrm{Fu}, 2010)$. $=38,1 / 87,2=0,4369$ or $43.69 \%$.

The value of the indicator indicates that the terms of use of loans by borrowing entities decreased by $56.3 \%$ (43.69-100). In order to determine the impact on the increase in the average duration of the use of credit changes only the first factor, it is necessary to calculate the index of the constant composition (Polach et al., 2012). The index of the average duration of the use of a loan of constant membership is:

$$
I_{t}=\frac{\sum t_{1} m_{1}}{\sum m_{1}} \div \frac{\sum t_{0} m_{1}}{\sum m_{1}} .
$$

$\mathrm{It}=38,1 /\left[\left(93,3^{*} 45324,4+728,2 * 175,33+18,4 * 8166,2\right) /(45324,4+175,33+8166,2)\right]=$ $=38,1 /(4506699,906 / 53665,93)=38,1 / 83,977=0,4537$ or $45,37 \%$.

The average duration of use of a loan due to a change in the terms of immobilization by the subjects credited by the bank can be determined:

$$
\Delta \bar{t}(t)=\frac{\sum t_{1} m_{1}}{\sum m_{1}}-\frac{\sum t_{0} m_{1}}{\sum m_{1}} .
$$

$\overline{\Delta t}(t)=38,1-83,977=-45,877$ days.

The influence of the second factor - structural changes in the composition of one-day repayment turnover on the increase in the average duration of credit use, is determined using the index of the influence of structural changes (Sufian and Habibullah, 2009). Structural change index:

$$
I_{s t r}=\frac{\sum t_{0} m_{0}}{\sum m_{1}} \div \frac{\sum t_{0} m_{0}}{\sum m_{0}} .
$$

$I_{\text {str. }}=83,977 / 87,2=0,963$ or $96,3 \%$. 
S. Andros, L. Melnyk, N. Butenko, H. Zaikina \& V. Tykhenko. Efficiency of Management of Loan Funds in the Banking Industry of Ukraine: Data of the Factor Analysis of Credit Turnover

As a result, the change in the average length of use of credit due to structural shifts in one-day turnover on redemption was: $\Delta \bar{t}($ str $)=83,977-87,2=3,23$ days.

The decrease in the average terms of credit use is due to a significant decrease in the duration of the use of mortgage loans from individuals and loans to legal entities by $54.63 \%$ (45.37-100), or 45.88 days. Structural changes had a great influence, which caused a decrease in the average duration of loan use by $3.7 \%(96.3-100)$, or by 3.23 days. Indices are a very effective tool in determining the rate of credit turnover (Heffernan and Fu, 2010). Using the data of Table 7, we calculate the indices of the velocity of circulation of loans for the duration of their use. Since the term of use of a loan is an inverse characteristic of its turnover, it is advisable to use the inverse ratio of indicators, that is, baseline data (in our study - 2016) divided by reporting data (2017), to analyze credit turnover (Andros, 2015).The index of variable composition is equal to:

$$
I_{n(t)}=\bar{t}_{0} \div \bar{t}_{1}
$$

$I_{n(t)}=87,2 / 38,1=2,2887$ or $228,87 \%$.

Index of permanent composition:

$$
I_{n(t)}=\frac{\sum t_{0} m_{0}}{\sum m_{1}} \div \frac{\sum t_{1} m_{1}}{\sum m_{1}}
$$

$I_{n(t)}=83,977 / 38,1=2,2041$ or $220,41 \%$.

If indexes of variable and constant composition are known, then the index of the influence of the structure can be calculated through the relationship of these indices (Lebas, 1995, Andros, 2015). Structure influence index:

$$
I_{s t r}=\frac{\sum t_{0} m_{0}}{\sum m_{0}} \div \frac{\sum t_{0} m_{1}}{\sum m_{1}} .
$$

$I_{s t r}=87,2 / 83,977=1,038$, or $103,83 \%$.

Thus, the turnover rate of mortgage loans to individuals and loans to legal entities increased by $128.87 \%$ (228.87-100). This in absolute terms amounted to 49.1 days (87.2-38.1). The increase in the average speed is due to the change in turnover in individual subjects, which amounted to $120.41 \%(220.41-100)$, or 45.88 days (83.977-38.1). Structural changes have a positive effect on the average velocity of credit, increasing the velocity of credit by $3.83 \%$ (103.83-100), or 3.23 days (87.2-83.977). The use of indices in the analysis allows us to determine also the absolute increase in the average duration of the use of a loan due to individual factors, which we find by subtracting the second fraction from the first fraction (if the index is a ratio of two averages), or as the difference of the numerator and denominator - for another form of the index (Prieto and Revilla, 2016; Tyrychtr, 2015). Referring to table 4, we note that the absolute increase in the average turnover in 2017 compared to 2016 was 5.32 turnover $(9.44-4.12)$, including due to changes in turnover in individual subjects - 4.068 turnover $(9,44-5,372$;

$\left.5,372=3,86^{*} 0,96287+0,49^{*} 0,01333+19,54^{*} 0,23795=3,7167+0,00653+4,649\right)$.

The increase in average turnover by 1,252 turnover $(5,372-4,12)$ led to favourable changes in the composition of average loan balances. Turnover indicators allow us to determine the effectiveness of the acceleration of credit turnover $\left(\bar{K}_{b}\right)$ (Shih et al., 2007). Indicators of economic efficiency are based on the classical scheme (Lebas, 1995, Andros, 2015). The principle of efficiency is the ratio of the result of economic activity and the costs (of resources used) associated with its receipt (Brignall, 2007; Dvorak et al., 2007). In our 
S. Andros, L. Melnyk, N. Butenko, H. Zaikina \& V. Tykhenko. Efficiency of Management of Loan Funds in the Banking Industry of Ukraine: Data of the Factor Analysis of Credit Turnover

study, efficiency is related to the relative release of turnover credit (Tan and Floros, 2014; Sulak and Vacik, 2005, Andros, 2015). We define it by the formula:

$$
\bar{K}_{B}=\left(t_{1}-t_{0}\right) \times m_{1}
$$

$$
\bar{K}_{6}=(38,1-87,2)^{*} 53665,93=-2634997,2 \text { thousand } \mathrm{UAH}
$$

The presented technique is a convenient addition to the traditional analysis of credit investments, carried out in commercial banks.

The turnover of loans is analyzed using the following indicators: the number of revolutions of credit funds, the duration of one turnover in days. The indicator is in inverse relationship - with increasing speed, the duration of one loan turnover decreases. Due to the increase in the rate of rotation of loans, credit resources are released from turnover, which may be involved in other active operations of the bank and generate additional profit.

Reducing the duration of one turnover (accelerating the turnover of loans) is influenced by reducing the amount of debt on loans, as well as an increase in the amount of loan repayment and a change in the average interest rate on loans. The deterioration of loan repayment and a decrease in the volume of loans issued increases the duration of one turnover. In order to increase liquidity, one should adhere to the level of large loans that is different from the normal level. It should be assumed that the debt on large loans should not exceed $50 \%$ of the actual credit investments.

Conclusions. A reliable financial basis for the activities of small and medium-sized businesses and corporations has led to a reduction in loan debt in 2017 by UAH 1319.9 million. This indicates an improvement in the quality of the loan portfolio for Credit Agricole Bank as a whole. In 2017, the level of repayment of loans extended to legal entities and consumer loans extended to individuals increased by $28.5 \%$ and $60.9 \%$, and mortgage loans extended to individuals decreased by $16.0 \%$, respectively. In general, in the loan portfolio in 2016, the duration of the use of loans by subjects was 87.2 days, and in the loan portfolio in $2017-38.1$ days. There is a tendency to a significant slowdown in the turnover of loans under the influence of changes in the structure of debt.

Reducing the duration of one turnover (accelerating the turnover of loans) is influenced by reducing the amount of debt on loans, as well as an increase in the amount of loan repayment and a change in the average interest rate on loans. The change in the average duration of loan use due to structural changes in the one-day repayment turnover was 3.23 days. The decrease in the average terms of credit use is due to a significant decrease in the duration of the use of mortgage loans from individuals and loans to legal entities for 45.88 days.

The turnover rate of mortgage loans to individuals and loans to legal entities increased by $128.9 \%$ and amounted to 49.1 days. Structural changes have a positive effect on the average velocity of credit, increasing the velocity of credit by $3.8 \%$ or 3.2 days. The increase in average turnover by 1.3 turnovers led to favourable changes in the composition of average loan balances. Due to the increase in the rate of rotation of loans, credit resources are released from turnover, which may be involved in other active operations of the bank and generate additional profit. Based on the factor analysis of the loan turnover, effective management of borrowed funds in the banking business of Ukraine (using the example of Credit Agricole Bank) has been proved. In order to increase liquidity, one should adhere to the level of large loans that is different from the normal level. It should be assumed that the debt on large loans should not exceed $50 \%$ of the actual credit investments.

Author Contributions: calculated average balances of credit investments, S.A.; analyzed the repayment of loans by business entities, S.A. and L.M.; calculated the share of loans by industry in the portfolio of the bank, S.A.; calculations of a one-day turnover on repayment of bank loans by business 

Industry of Ukraine: Data of the Factor Analysis of Credit Turnover

entities, S.A. and H.Z; calculated the duration of use of bank loans by business entities, S.A.; the factors affecting the change in the rate of turnover of credit operations using the index method are analyzed, S.A. and V.T; the index of the average duration of use of the loan of a constant composition is calculated S.A.; the average duration of use of bank loans by business entities has been determined S.A.; the structural change index, variable composition index, constant composition index, structure influence index are calculated S.A. and H.Z.; the calculation of the reasonable limits of attracting each type of resources and the effective interest rate to ensure the increasing return on the production of banking credit products and increasing the share of the banking sector in creating the gross domestic product of the country S.A. and L.M.

Funding: The article was prepared in the framework of the fundamental research work «Development of the Theoretical and Methodological Foundations of Financial and Credit Support of the Agricultural Sector of the Economy» (state registration number 0116U000063) of the National Scientific Center «Institute of Agrarian Economics».

\section{References}

Andros, S.V. (2015). Formation and Implementation of the Strategy of Credit and Investment Activity of Banks: Theory, Methodology, Practice. Monograph. Kyiv: State Higher Educational Institution «University of Banking», 550.

Annual Financial Ctatements of "Credit Agricole Bank» 2017. (2018). Available from: https://credit-agricole.ua/storage/files/creditagricole-audit-2017-ukr.pdf (Accessed 17.04.2018).

Athanasoglou, P.P., Brissimis, S.N, and Delis, M.D. (2008). Bank-Specific, Industry-Specific and Macroeconomic Determinants of Bank Profitability. Joumal of Intemational Financial Markets, Institutions and Money, 18(2), 121-136.

Behr, P. and Guettler, A. (2007). Credit Risk Assessment and Relationship Lending: An Empirical Analysis of German Small and Medium-Sized Enterprises. Journal of Small Business Management, 45(2), 194-213.

Berger, A.N. and Udell, G. (1998). The Economics of Small Business Finance: The Roles of Private Equity, Debt Markets in the Financial Growth Cycle. Journal of Banking and Finance, 22(8), 613-673.

Brignall, T. J. S. (2007). A Financial Perspective on Performance Management. In Irish Accounting Review, 14, Iss. 1, 15-29.

Brcak, J. (2010). Makroekonomie. Vydavatelstvi a Nakladatelstvi Ales Cenek, 292.

Cemohorska, L. and Kula, V. (2017). The Effect of M3 Monetary Aggregates and Bank Loans on the Economic Growth of Countries in the Eurozone, the USA and Japan. Scientific Papers of the University of Pardubice. Series D. Faculty of Economics and Administration, 40 (2), XXIV, 27-38.

Civelek, M. and Kljucnikov A. (2018). Sectoral and International Diversities in the Perception of Bank Financing: Evidence from Slovak and Czech Smes. Scientific Papers of the University of Pardubice. Series D. Faculty of Economics and Administration, 44 (3), XXVI, 53-64.

Conti, G., Fruhwirth-Schnatter, S., Heckmanc, J.J., Piateke, R. (2014). Bayesian Exploratory Factor Analysis. In Journal of Econometrics, 183, Iss. 1, 31-57. Doi: 10.1016/j.jeconom.2014.06.008.

Dietsch M. and Petey, J. (2002). The Credit Risk in SMEs Loans Porffolios: Modeling Issues, Pricing, and Capital Requirements. Journal of Banking and Finance, 26, 303-322.

Dohcheva, D. (2009). Credit Rationing In Agricultural Credit Markets In Bulgaria. Trakia Journal of Sciences, 7 (3), 57-62.

Dvorak, J., Heralecky, T., DvoraK, J. (2007). Trendy v Elektronickem Bankovnictvi. Scientific Conference on the Occasion of 15th Anniversary of the Establishment of Faculty of Business and Management Brno University of Technology, 1-5.

Golin, J. (2001). The Bank Credit Analysis Handbook: A Guide for Analysts, Bankers and Investors. John Wiley \& Sons (Asia) Pre Ltd. Heffernan, S. and Fu, M. (2010). Determinants of Financial Performance in Chinese Banking. Applied Financial Economics, 20(20), 1585-1600.

Homungova, J. and Milichovsky F. (2016). Financial Performance Evaluation of the Czech Agricultural Companies with Factor

Fnalysis. Scientific Papers of the University of Pardubice. Series D. Faculty of Economics and Administration, 37 (2), XXII, 26-38. Jac, I., Sedlar, J., Zajcev, A. a Zajcev, V. (2013). Principles of Creating a Cost-cutting Strategy At an Enterprise by Means of the Lean

Production Concept E+M. Ekonomie a management. Vyd. Liberec: Technicka Univerzita v Liberci, 75-84.

Khalid, H.A. and Kalsom, A.W. (2014). Financing of Small and Medium Enterprises (SMEs): Determinants of Bank Loan Application. African Journal of Business Management, 8(17), 717-727.

Kotane, I., Kuzmina-Merlino, I. (2012). Assessment of Financial Indicators for Evaluation of Business Performance. In European Integration Studies, 6, 216-224. Doi: 10.5755/j01.eis.0.6.1554.

Lebas, M.J. (1995). Performance Measurement and Performance Management. International Journal of Production Economics, 41, Iss. 1, 23-35.

Neely, A. (2004). Business Performance Measurement: Theory and Practice. Cambridge University Press. 
S. Andros, L. Melnyk, N. Butenko, H. Zaikina \& V. Tykhenko. Efficiency of Management of Loan Funds in the Banking Industry of Ukraine: Data of the Factor Analysis of Credit Turnover

O'sullivan, D., Abela, A.V., Hutchinson, M. (2009). Marketing Performance Measurement and Firm Performance: Evidence from European High-Technology Sector. European Journal of Marketing, 43, Iss. 5/6, 843-862. Doi: 10.1108/03090560910947070.

Polach, J., Drabek, J., Merkova, M., Polach, J. jr. (2012). Realne a Financni Investice. Vydani Praha: C.H. Beck, 280.

Prieto, I.M., Revilla, E. (2016). Learning Capability and Business Performance: a Nonfinancial and Financial Assessment. In Leaming Organization, 13, Iss. 2, 166-185. Doi: 10.1108/09696470610645494.

Roodman, D.M. (2009). A Note on the Theme of Too Many Instruments. Oxford Bulletin of Economics and Statistics, 71(1), 135-158.

Shih, V., Zhang, Q. and Liu, M. (2007). Comparing the Performance of Chinese Banks: a Principle Component Approach. China Economic Review, 18(1), 15-34.

Sufian, F. and Habibullah, M.S. (2009). Bank Specific and Macroeconomic Determinants of bank Profitability: Empirical Evidence from the China Banking Sector. Frontier of Economics in China, 4(2), 274-291.

Sulak, M., Vacik, E. (2005). Mereni Vykonnosti Firem. Praha: Eupress, 90.

Tan, Y. and Anchor, J. (2016). Stability and Profitability in the Chinese Banking Industry: Evidence from an Auto-Regressive-Distributed Linear Specification. Journal of Investment Management and Financial Innovations, 13, Iss. 4, 155-163. Available from:

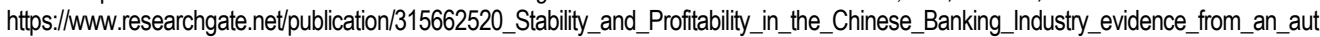
o-regressive-distributed_linear_specification (Accessed 07.12.2018).

Tan, Y. and Floros, C. (2014). Risk, Profitability and Competition: Evidence from the Chinese Banking, Journal of Developing Areas, 48(3), 303-319.

Tyrychtr, J., Ulman, M., Vostrovsky, V. (2015). Evaluation of the State of the Business Intelligence Among Small Czech farms. In Agricultural Economics, 61, Iss. 2, 63-71. Doi: 10.17221/108/2014-AGRICECON.

Zhang, J. J., Lawrence, B., Anderson, Ch. K. (2015). An Agency Perspective on Service Triads: Linking Operational and Financial Performance. Journal of Operations Management, 35, 56-66. Doi: 10.1016/j.jom.2014.10.005.

C. Андрос д.е.н., доцент, Національний науковий центр «lнститут аграрної економіки» (Україна);

Л. Мельник, д.е.н., доцент, Уманський національний університет садівництва (Україна);

Н. Бутенко, д.е.н., професор, Київський національний університет імені Тараса Шевченка (Україна);

Г. Зайкіна, к.е.н., Український державний університет залізничного транспорту (Україна);

В. Тихенко, к.е.н., Сумський державний університет (Україна).

Ефективність управління позиковими коштами в банківській індустрії України: дані факторного аналізу кредитного обороту

В cmammi проаналізовано темпи кредитного обороту по галузях економіки і за видами кредитів з використанням показників динамічного діапазону, індексів середніх значень і сукупних показників. Мета статті полягає в економічному обгрунтуванні ефективності управління кредитними ресурсами в комериійних банках на основі фракторного аналізу кредитного обороту по галузях економіки як умови оптимізації діяльності банку. Опрацювання літератури засвідчує, що управління кредитними ресурсами в комерційних банках обмежується застосуванням неадаптованих до українських реалій західних методик. Актуальність статті полягає в необхідності використання методів економікоматематичного моделювання для оптимізації процесу управління позиковими коштами в банківській індустрії України. Розраховані середні залишки кредитних вкладень. Аналізується погашення кредитів суб'єктами господарювання. Розрахунки обсягів кредитного обороту спираються на реальні показники фрінансової звітності Креді Агріколь Банку. Періодом дослідження обрано 2016-2017 роки. Розрахована частка кредитів по галузях у портфелі банку. Виконано розрахунки одноденного обороту з погашення банківських кредитів суб'єктами господарювання. Розрахована тривалість використання банківських кредитів суб'єктами господарювання. Проаналізовано фактори, які впливають на зміну швидкості обороту кредитних операцій з використанням індексного методу. Наведено розрахунки індексу середньої тривалості використання кредиту постійного складу. Визначено середня тривалість використання банківських кредитів суб'єктами господарювання. Розраховані індекс структурних змін, індекси змінного і постійного складу, індекс впливу структури. У статті використано методи фракторного аналізу, теорії ймовірності, методи економіко-математичної статистики. Ефективність управління позиковими коштами в банківській індустрії України (на прикладі Креді Агріколь Банку) була підтверджена даними фракторного аналізу оборотності кредитів. В систему завдань, що вирішуються пропонованими моделями, включається розрахунок обгрунтованих меж залучення кожного виду ресурсів і ефективної процентної ставки для забезпечення зростаючої віддачі від виробництва банківських кредитних продуктів та підвищення частки банківського сектора у створенні валового внутрішнього продукту країни.

Ключові слова: банк, ефективність, індекси, кредитний оборот, позика, процентна ставка, сума, термін, управління.

Manuscript received: 29.07.2019.

(C) The author(s) 2019. This article is published with open access at Sumy State University. 